\title{
DUCHOWIEŃSTWO NIŻSZE EPOKI POTRYDENCKIEJ W ŚWIETLE PROTOKOŁÓW WIZYTACJI BISKUPÓW. PRZYKŁAD PARAFII PW. WSZYSTKICH ŚWIĘTYCH W BRZEZINACH ${ }^{1}$
}

Streszczenie. W artykule zostało przedstawione duchowieństwo niższe epoki potrydenckiej na przykładzie parafii Brzeziny. Wspólnota okresie staropolskim należała do diecezji krakowskiej. Jako główne źródło do badania tego zagadnienia posłużyły akta wizytacji kanonicznych. Struktura artykułu jest chronologiczna do kolejnych okresów posługi kapłanów, którzy pracowali w parafii od XVI do XVIII w. W opisach kapłanów zawarto informacje o ich pochodzeniu, wykształceniu, karierze kapłańskiej a także ich postawom moralnym. Obraz duchowieństwa parafii Brzeziny został również porównany ze stanem badań duchowieństwa w epoce potrydenckiej, której założeniem było wzmocnienie roli kapłana we wspólnocie kościelnej.

Słowa kluczowe: Sobór Trydencki, Kontrreformacja, diecezja krakowska, duchowieństwo niższe, Brzeziny.

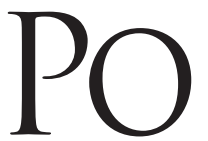

Soborze Trydenckim (1545-1563) hierarchia kościelna dążyła do wzmocnienia pozycji i autorytetu duchownych, nadszarpniętych skandalami obyczajowymi i patologiami². Dużą rolę przywiązywano również do wykształcenia duchownych. W czasie 23. Sesji Soboru Trydenckiego uchwalono kanony, które zwracały szczególną uwagę na wykształcenie kapłanów. Podniesieniu poziomu intelektualnemu kleru

${ }^{1}$ Artykuł jest poszerzoną wersją referatu o tym samym tytule zaprezentowanym na XXVI Ogólnopolskim Zjeździe Historyków Studentów w Łodzi w dniu 18 IV 2018.

2 Ibidem, s. 205. 
służył m.in. obowiązek erygowania seminariów duchownych przez biskupów, stosownie do miejsca i rozmiaru diecezji ${ }^{3}$. Kościół miał pełnić rolę przewodnika i opiekuna, dlatego też kapłan miał pełnić ważną rolę w społeczeństwie ${ }^{4}$.

Z tego powodu duchowieństwo stanowi istotne zagadnienie historii każdej parafii. Stąd też kapłanom należytą uwagę poświęcono w dwóch podstawowych pracach dotyczących - parafii w średniowieczu - autorstwa Eugeniusza Wiśniowskiego ${ }^{5}$ - a także w nowożytności - Stanisława Litaka ${ }^{6}$. $\mathrm{Na}$ uwagę zasługują również prace dotyczące poszczególnych diecezji ${ }^{7}$, a także innych struktur Kościoła Katolickiego, będących owocem badań Ośrodka Badań nad Geografią Historyczną Kościoła w Polsce Katolickiego Uniwersytetu Lubelskiego ${ }^{8}$. Biorąc pod uwagę zakres terytorialny niniejszego artykułu, najistotniejszą rolę odgrywa monumentalna praca Bolesława Kumora dotycząca diecezji krakowskiej ${ }^{9}$. Do badaczy historii tej diecezji należą również Jan Wiśniewski, autor licznych prac poświęconych poszczególnym dekanatom ${ }^{10}$, a także Waldemar Kowalski ${ }^{11}$. Wreszcie, powstały również prace poświęcone duchowieństwu, w głównej mierze autorstwa Jana Szczepaniaka ${ }^{12}$.

${ }^{3}$ Dokumenty soborów powszechnych, t. IV, oprac. A. Baron, H. Pietras, s. 705-713.

${ }^{4}$ D. Główka, Przewodnik, inicjator, adwersarz? Uwagi o miejscu plebana w społeczności wiejskiej w XVII-XVIII wieku na przykładzie diecezji płockiej, [w:] Dwór, plebania, rodzina chłopska, Szkice z dziejów wsi polskiej XVII i XVIII wieku, red. M. Ślusarska, Warszawa 1998, s. 57.

${ }^{5}$ E. Wiśniowski, Parafie w średniowiecznej Polsce, Lublin 2004.

${ }^{6}$ S. Litak, Parafie.

7 A. Liedtke, Zarys dziejów diecezji chełmińskiej do 1994, Pelpin 1994; Kościół płocki XI-XX wieku. Jubileuszowa Księga pamiatkowa 900-lecia Diecezji, cz. 1, red. J. Kłoczowski, „Studia Płockie" 1975, nr 3; J. Ataman, Zarys dziejów diecezji przemyskiej obrzqdku łacińskiego, Przemyśl 1985; B. Kumor, Diecezja tarnowska. Dzieje ustroju i organizacji 1786-1985, TarnówKraków 1985.

${ }^{8}$ P. Szafran, Rozwój średniowiecznej sieci parafialnej w Lubelskiem, Lublin 1998; A Olczyk, Sieć parafialna biskupstwa warmińskiego do roku 1525, Lublin 1961.

9 B. Kumor, Dzieje diecezji krakowskiej, t. 1-4, Kraków 1998-2002.

10 J. Wiśniewski, Dekanat miechowski, Radom 1917; idem, Dekanat opatowski, Radom 1907; idem, Dekanat radomski, Radom 1911.

${ }^{11}$ W. Kowalski, Uposażenie parafii archidiakonatu sandomierskiego $w$ XV-XVIII wieku, Kielce 1998; idem, Change in Continuity: Post-Tridentine Rural and Township Parish Life in the Cracow Diocese, „Sixteenth Century Journal” 2004, t. 35, nr 3, s. 689-715; idem, Parafia Trójcy Świętej w Jędrzejowie w epoce przedrozbiorowej, [w:] W. Kowalski, D. Olszewski, Parafia Trójcy Świętej w Jędrzejowie na tle dekanatu. Zarys dziejów, Kielce 2003, s. 7-226.

12 J. Szczepaniak, Duchowieństwo diecezji krakowskiej w XVIII wieku. Studium prozopograficzne, Kraków 2010; Katalog duchowieństwa diecezji krakowskiej na podstawie krakowskich ksiąg święceń (1646-1789), t. 1-4, Kraków 2008-2009; idem, Spis prepozytów i plebanów diecezji krakowskiej, Kraków 2008; idem, Katalog parafii i duchowieństwa diec. krakowskiej 1748, Kraków 2006. 
Pewną niewielką częścią diecezji krakowskiej w okresie staropolskim była parafia pw. Wszystkich Świętych w Brzezinach, powstała około $1440 \mathrm{r}$. na obszarze na południe od Kielc i na północ od rzeki Czarnej Nidy ${ }^{13}$. Należy zaznaczyć że od momentu powstania parafii aż do 1726 r. prawo nominacji proboszcza parafii posiadał biskup krakowski. Następnie patronat przeszedł na nowo powstałe Seminarium Duchowne w Kielcach. Stan ten nie zmienił się do końca okresu staropolskiego. Do 1795 r. prawo patronatu w parafii Brzeziny posiadało więc duchowieństwo. Jakkolwiek, zmiana która nastąpiła w 1726 r., miała dalekie konsekwencje zarówno na obsadę probostwa w parafii, a także jej duszpasterstwo.

Celem niniejszego artykułu będzie omówienie zagadnienia duchowieństwa parafii Brzeziny od czasu Soboru Trydenckiego (1545-1563) do III rozbioru Rzeczypospolitej w 1795 r., który przyniósł zmiany w granicach administracyjno-duszpasterskich Kościoła na ziemiach polskich. Badanie dziejów duchowieństwa parafii Brzeziny niesie ze sobą takie problemy badawcze jak pochodzenie i wykształcenie księży czy przebieg ich dotychczasowej posługi kapłańskiej. W niniejszym artykule poszczególni duchowni zostaną opisani chronologicznie, ze szczególnym uwzględnieniem proboszczów parafii, którzy z racji źródeł są bardziej uchwytni w badaniu niż ich zastępcy.

Podstawowym źródłem do badania dziejów parafii w okresie potrydenckim, a więc również duchowieństwa, są akta wizyt kanonicznych.

Parafia Brzeziny w okresie staropolskim została zwizytowana pięć razy, w następujących latach: $1597^{14}, 1711^{15}, 1738^{16}, 1747^{17}, 1782^{18}$. Analiza protokołów wizytacyjnych, które w większości znajdują się w Archiwum Kurii Metropolitalnej w Krakowie, została poszerzona o kwerendę archiwaliów dotyczących parafii Brzeziny, a znajdujący się w Archiwum Diecezjalnym w Kielcach. Dzięki temu możliwe stało się uzupełnienie i poszerzenie analizy poszczególnych zagadnień, jak również, z racji charakteru źródła, wzajemne potwierdzenie się informacji zawartych w archiwaliach.

Pierwsze wzmianki o kapłanach parafii Brzeziny pojawiają się w Liber beneficiorum Jana Długosza ${ }^{19}$. Księga uposażeń diecezji krakowskiej wymienia plebana parafii (nie określając jego danych personalnych), opisując należne

${ }^{13}$ B. Rzewuska-Kurzeja, Rozwój sieci parafialnej w prepozyturze kieleckiej w średniowieczu, „Nasza Przeszłość” 1983, t. 59, s. 92.

${ }^{14}$ AKMKr AV Cap 8, s. 1, 61-62.

15 AKMKr AV 17, s. 432-534.

16 AKMKr AV 27, s. 41-46, 269-277.

17 AKMKr AV 37, s. 89-94, 402-414.

${ }_{18}$ ADK II PB-XI/5, rkps s. 54r - 61r.

19 J. Długosz, Liber beneficiorum dioecesis Cracoviensis, t. 1, wyd. A. Przezdziecki, Kraków 1864, s. 457. 
mu uposażenia. Należały do nich pola $i$ łąki wolne ${ }^{20}$. Sołtys wsi był zobowiązany do płacenia dziesięciny kościołowi i plebanowi w Brzezinach. Są to wszystkie zachowane informacje o duchownych parafii z XV w.

Kolejne informacje o duchownych pochodzą dopiero z okresu wizytacji radziwiłłowskiej ${ }^{21}$ z 1597 r. Plebanem kościoła w Brzezinach był w tym czasie Jan Dobiecki, który w czasie wizytacji miał rezydować w miejscowości Pierzchnica. Wizytator nie wiedział, czy dany kapłan posiadał odpowiednią dyspensę. Dekret II 6. Sesji Soboru Trydenckiego (1545-1563) mówił bowiem o obowiązku rezydowania w swoich parafiach biskupów, proboszczów i innych kuratusów, czyli duchownych sprawujących pieczę duszpasterską ${ }^{22}$. W parafii posługiwał również wikary - Jakub z Korytnicy. Duchowny ten został wyświęcony przez biskupa Marcina Białobrzeskiego, sufragana krakowskiego (1566-1576) ${ }^{23}$, któremu winien był płacić osiem grzywien. Z podanych informacji wynika, iż na ówczesnym wikarym mogła spoczywać cała piecza duszpasterska w zastępstwie plebana, co było spowodowane jego czasową lub stałą nieobecnością. Nie jest to rzadkie zjawisko w Kościele, nawet epoki potrydenckiej ${ }^{24}$. Jakub z Korytnicy, syn Jana otrzymał pierwsze z czterech wyższych święceń - subdiakonat - po złożeniu egzaminu 18 września 1574 r. przeprowadzanego przez Stanisława Dąbrowskiego i Zygmunta ze Stężycy ${ }^{25}$, pełniąc już funkcję wikarego w Kielcach, a trzy miesiące później zdał egzamin przed święceniami diakonatu. Natomiast 19 marca 1575 r. był przygotowany do święceń prezbiteratu. Przystępując do święceń subdiakonatu, jeśli odbyły się zgodnie z obowiązującym ówcześnie prawem kanonicznym, Jakub z Korytnicy musiał ukończyć 22 . rok życia ${ }^{26}$. Jego prowizorem był Jakub Laskowski, ówczesny pleban parafii Brzeziny ${ }^{27}$. Wynika z tego, iż pleban sam starał się o ordynanda i następnym miejscem jego pracy duszpasterskiej była właśnie parafia Brzeziny. Na uwagę zasługuje fakt, że Jakub z Korytnicy był wikarym, pomimo tego, iż funkcję proboszcza pełnił już inny kapłan. Mógł więc on pełnić swoją posługę przez dłuższy czas lub był wikarym po raz kolejny w parafii Brzeziny.

20 Ibidem.

${ }^{21}$ AKMKr AV Cap 8, s. 1, 61-62.

22 Dokumenty soborów powszechnych, t. 4, oprac. A. Baron, H. Pietras, Kraków 2004, s. 319-321; I. Siekierska, Obowiq̨zek mszalny w średniowiecznej Polsce, Warszawa 2003, s. 108.

${ }^{23}$ W. Budka, Białobrzeski Marcin, [w:] Polski Słownik Biograficzny (dalej PSB) t. II, Kraków 1936, s. 14-15.

${ }^{24}$ S. Litak, Parafie, s. 155.

${ }^{25}$ Księga egzaminów do święceń $w$ diecezji krakowskiej z lat 1573-1614, red. Z. Pietrzyk, Kraków 1991, s. 37.

26 J. Szczepaniak, Duchowieństwo, s. 238.

27 Księga egzaminów, s. 212. 
XVII w., pomimo ważnego wydarzenia w dziejach parafii, jakim była budowa nowej, murowanej świątyni, nie obfituje w źródła do dziejów parafii Brzeziny. Stąd też jedynym potwierdzonym kapłanem z tego okresu jest Wojciech Liszkowic. Zburzył on stary, drewniany kościół i wybudował nowy, murowany ${ }^{28}$.

Kolejne stulecie z racji dużej ilości źródeł, jest najbogatsze, jeśli chodzi o informacje o duchownych parafii Brzeziny. Pierwszym plebanem parafii Brzeziny w XVIII w. był Wawrzyniec (Laurenty) Cedrowicz. Wizytacja z $1711 \mathrm{r}^{29}$ dostarcza informacji o przebiegu kariery duchownego. Protokoły zawierają puste miejsca przy informacjach o dacie przyjętych święceń i objęciu poszczególnych beneficjów, przekazują natomiast przebieg posługi. Wawrzyniec Cedrowicz, syn Jana, przyjął niższe święcenia kapłańskie 24 września $1689 \mathrm{r}^{30}$ Po przyjęciu prezbiteratu 16 maja $1693 \mathrm{r}$. został on ustanowiony mansjonarzem Katedry Wawelskiej. Następnie był penitencjarzem Kościoła Archiprezbiterialnego Krakowskiego (zapewne chodzi o Kościół Mariacki). Kolejną posługą było stanowisko preceptora Szpitala Najświętszej Trójcy w Kielcach, na którego został ustanowiony 16 lutego $1699 \mathrm{r}^{31}$ Wreszcie, został mianowany na proboszcza brzezińskiej parafii 17 czerwca 1710 r. Na ostatnie beneficjum miał odpowiednie upoważnienie przez rezerwację. W dekrecie reformacyjnym wizytator zwraca uwagę na kumulację dwóch beneficjów i dalszą niemożność istnienia takiego stanu. Ksiądz Wawrzyniec Cedrowicz nie posiadał bowiem odpowiedniej dyspensy Stolicy Apostolskiej. Tekst dekretu zwraca też uwagę na to, że niemożliwe jest posiadanie trzech beneficjów. Czy duchowny posiadał zatem jeszcze jedno uposażenie? Być może ks. Cedrowicz mógł pobierać dochód jeszcze z funkcji pereceptora. Wizytator upominał się o rezygnację z jednego $\mathrm{z}$ tych beneficjów. Problem kumulacji beneficjów był jedną z bolączek polskiego Kościoła, również w okresie potrydenckim ${ }^{32}$. Wiązało się z tym przede wszystkim nieprzebywanie proboszczów w parafii. Zjawisko to powodowało, iż ciężar pracy duszpasterskiej spadał na wikarych. Ponadto, był to przykład bogacenia się kleru. Ostatecznie Wawrzyniec Cedrowicz posiadał beneficjum przy Szpitalu Kieleckim do r. $1712^{33}$. Kapłan zastosował się więc do dekretów reformacyjnych w stosunkowo niedługim czasie.

\footnotetext{
28 ADK II PB-XI/1, s. 76.

29 AKMKr AV 17, s. 432r.-534.

30 J. Szczepaniak, Katalog duchowieństwa, t. 1, Kraków 2008, s. 123.

31 AKMKr AV 17, s. 432r.

32 J. Szczepaniak, Duchowieństwo, s. 322.

33 F. Puchalski, Seminarium kieleckie. Rys historyczny i dokumenty, Kielce 1901, s. 82.
} 
Oprócz proboszcza na parafii znajdował się również vicarius applicatus Stanisław Dbalski. Z treści aktu wizytacyjnego wynika, że dbał on o sprawowanie sakramentów, jednak zbyt często odwiedzał karczmę. Pod tym zwrotem kryje się, iż wikary często ulegał nałogowi pijaństwa. Dlatego też w dekrecie reformacyjnym wikary pod groźbą usunięcia z posady zobowiązany jest do nie odwiedzania karczmy i powierzony opiece proboszcza.

Duchowni parafii Brzeziny z początku drugiej dekady XVIII w. choć wypełniają swoje obowiązki, nie są wolni od złych skłonności. Te wady są jednak nierzadko spotykane wśród ówczesnego duchowieństwa ${ }^{34}$.

Następcą ks. Cedrowicza na stanowisku proboszcza był ks. Kazimierz Maliński, syn Mateusza ${ }^{35}$. Urodził się on w 1703 r. w Masłowie ${ }^{36}$. Tuż przed otrzymaniem święceń subdiakonatu (25 lipca 1728 r.) otrzymał prowizję na parafię w Brzezinach, udzieloną mu przez ówczesnego proboszcza - Wawrzyńca Cedrowicza. Pełnił więc on funkcję wikarego na prowizji. Został wyświęcony na kapłana 21 stycznia 1729 r. Proboszczem parafii Brzeziny został ustanowiony w piątek, 5 kwietnia $1737 \mathrm{r}$. W tym samym dniu został również wprowadzony na stanowisku sędziego Sądu Biskupiego ${ }^{37}$. Już jednak w 1747 r. ks. Maliński posiadał jedno beneficjum. Według kolejnych wizytatorów z lat 1739 i 1747 ówczesny proboszcz prowadził prawe życie i dobrze sprawował duszpasterstwo ${ }^{38}$. Posiadał również niezbędne zgody do udzielania Sakramentu Pokuty i Pojednania.

W czasie posługi ks. Malińskiego nie było wikarego. W drugiej wizytacji za jego probostwa zostało stwierdzone iż nie wystarcza dochodów na zastępcę proboszcza, nie ma należnej fundacji dla wikarego ${ }^{39}$. W $1747 \mathrm{r}^{40}$ pojawia się jednak wzmianka o pomocy duszpasterskiej w ramach służby wikarego, która jednak nie miał oficjalnego upoważnienia i zezwolenia. Był nim ojciec franciszkanin, niewymieniony jednak z imienia i nazwiska. Prawdopodobnie mógł być to zakonnik pochodzący z klasztoru franciszkańskiego w Chęcinach. Przemawia za tym bliskość tego konwentu $(10 \mathrm{~km})$. Jednak taka forma pomocy zakonnika, bez oficjalnego pozwolenia, niosła określone konsekwencje. W dekrecie reformacyjnym, wizytator stwierdził iż zakon-

${ }^{34}$ Vide: J. Tazbir, Znaczenie obyczajów kleru dla rozwoju i upadku polskiej reformacji, „Odrodzenie i Reformacja w Polsce” 1963, t. 8, s. 91-107; idem, Staropolski antyklerykalizm, „Kwartalnik Historyczny" 2002, z. 3, s. 13-22.

${ }_{35}$ AKMKr AV 27, s. 44; AKMKr AV 37, s. 92-93; J. Szczepaniak, Katalog duchowieństwa, t. 2, s. 665 .

${ }^{36}$ J. Szczepaniak, Katalog parafii i duchowieństwa, s. 55.

${ }^{37}$ AKMKr AV 27, s. 44.

38 Ibidem, AKMKr AV 37, s. 93.

39 AKMKr AV 27, s. 45; AKMKr AV 37, s. 93.

${ }^{40}$ AKMKr AV 37, s. 93. 
nik który nie posada oficjalnego zezwolenia na działalność duszpasterską, nakłada na siebie ipso facto suspensę. Przypomina w tym aspekcie postanowienia II Synodu Lubelskiego (?), a dokładnie jego 13. rozdział ${ }^{41}$.

Ks. Kazimierz Maliński pracował w parafii aż do swojej śmierci. Zmarł 4 listopada 1769 r. w Brzezinach. Przed śmiercią przyjął sakramenty i został pochowany w krypcie kościelnej ${ }^{42}$.

Następnym proboszczem brzezińskim był Kazimierz Pietraszewski. Został on mianowany na plebana 28 kwietnia $1769^{43}$. Nie wiadomo, w którym roku dokładnie przestał być plebanem. Opis beneficjum 1792 r. wspomina o sporządzeniu przez niego inwentarza w 1774 r. (który się jednak nie zachował).

Kolejnym proboszczem parafii Brzeziny był ks. Andrzej Dachnowski ${ }^{44}$, komunista - duchowny ze Zgromadzenia Księży Życia Wspólnego (Institutum Sacerdotum Saecularium in Communi Viventium). Obecność kapłana ze zgromadzenia zakonnego w parafii związana jest z opieką tej wspólnoty nad Seminarium Kieleckim ${ }^{45}$, a także wspomnianym już wcześniej prawem do patronatu, prezenty i części dochodów tegoż seminarium do parafii Brzeziny $^{46}$. W dokumencie erekcyjnym seminarium kieleckiego z 3 czerwca 1727 r., biskup krakowski (1720-1732) Felicjan Szaniawski ${ }^{47}$ postanowił, że dopiero po śmierci ówczesnego plebana wspólnota zakonna wyznaczy duszpasterza na każde kolejne trzy lata ${ }^{48}$. Dlaczego zatem nie stało się to już w 1737 r., gdy beneficjum brzezińskie otrzymał ks. Kazimierz Maliński? Być może związane jest to z wcześniejszymi ustaleniami pomiędzy Wawrzyńcem Cedrowiczem i jego następcą, które postanowił uszanować regens seminarium. W aktach wizytacyjnych ${ }^{49}$ nie ma wzmianek o tym, aby Maliński był bartoszkiem $^{50}$.

Andrzej Dachnowski urodził się w 1726 r. w województwie lubelskim. Święcenia kapłańskie otrzymał w 1757 r. i należał do diecezji krakowskiej. Sakrament świeceń przyjął jednak w Warszawie z rąk ówczesnego biskupa

${ }^{41}$ Ibidem, s. 94; synod niezidentyfikowany.

${ }^{42}$ ADK PBRZ 13/1769.

43 J. Szczepaniak, Spis prepozytów, s. 30.

${ }^{44}$ ADK II B-XI/1, s. 12.

${ }^{45}$ M. Brudisz, Księża Życia Wspólnego, [w:] Encyklopedia katolicka (dalej EK), t. 10, Lublin 2004, k. 119.

${ }^{46}$ AKMKr AV 27, s. 44; AKMKr AV 37, s. 90.

47 B. Kumor, Dzieje, t. 3, s. 528.

${ }^{48}$ Ibidem, s. 487.

49 AKMKr AV 27, s. 45; AKMKr AV 37, s. 93.

50 Polska nazwa zwyczajowa księży ze Zgromadzenia Księży Życia Wspólnego, por: M. Brudzisz, Księża. 
inflanckiego (1753-1777) Antoniego Kazimierza Ostrowskiego (1713-1784), późniejszego Prymasa Polski ${ }^{51}$. Duchowny został instytuowany na to beneficjum 4 lutego 1776 r. w Sądach Zadwornych Biskupich, za prezentą ${ }^{52}$ Tomasza Lipińskiego, archidiakona Kolegiaty Kieleckiej, regensa Seminarium Duchownego w Kielcach (1775-1777) i prezesa Zgromadzenia ${ }^{53}$. Zgodnie $\mathrm{z}$ uprawnieniami regensa, został mianowany początkowo na 3 lata ${ }^{54}$. W listopadzie 1781 odprawił swoje rekolekcje ${ }^{55}$. Informacja ta wiąże się z dbałością wizytatorów o stan moralny duchowieństwa, na co nacisk położono po Soborze Trydenckim ${ }^{56}$. Jednocześnie pełnił funkcję ekonoma seminarium, dlatego też nie mógł wypełniać należycie swoich obowiązków. W 1791 r. nie posiadał żadnych innych beneficjów, które byłyby niezgodne z obowiązującym prawem kanonicznym ${ }^{57}$. Z racji pełnienia innych funkcji, proboszcza w obowiązkach wyręczał wikary. Dodatkowo, beneficjum parafii Brzeziny było przeznaczone jako tytuł kanoniczny do święceń dla 2-3 alumnów kieleckiego seminarium ${ }^{58}$. Już w 1777 r. ówczesny proboszcz udzielił prowizji klerykowi święceń niższych Franciszkowi Janiszowskiemu ${ }^{59}$. Był on alumnem seminarium kieleckiego. Kolejny vicarius providus to Krzysztof Przemyk, syn Jana $^{60}$. Święcenia niższe otrzymał 20 września 1783 r., natomiast prowizję z rąk ks. Andrzeja Dachnowskiego 24 czerwca 1785 r. W przypadku wyżej wymienionych wikarych zasadne wydaje się pytanie, czy pełnili oni posługę w rzeczywistości, czy mieli oni tylko dochody z wikariatu z powodu przysługującego seminarium prawa do uposażenia. W wizytacji z 1782 r. pojawia się informacja o posługującym przy parafii vicarius applicatus Józefie Zabłockim $^{61}$. Kapłan ten urodził się w 1734 r. Święcenia przyjął w 1776 r. z rąk sufragana płockiego (1760-1775) Dominika Kiełczewskiego ${ }^{62}$. Na aplikację

${ }^{51}$ H. Dymnicka-Wołoszyńska, Antoni Kazimierz Ostrowski, [w:] PSB, t. 24, Warszawa 1979, s. 540-546.

${ }^{52}$ Prezenta - prawo do przedstawienia władzy kościelnej kandydata na urząd kościelny lub beneficjum; G. Wojciechowski, Prezenta, [w:] EK, t. 16, Lublin 2012, k. 394.

53 F. Puchalski, Seminarium, s. 48.

${ }^{54}$ ADK II PB-XI/5, s. 59.

55 Ibidem.

56 S. Litak, Parafie, s. 205.

57 ADK II PB-XI/I, s. 12.

58 T. Wróbel, Dzieje seminarium duchownego w Kielcach na przestrzeni 250 lat, [w:] Księga jubileuszowa 1727-1977, Kielce 1977, s. 61.

${ }^{59}$ J. Sczepaniak, Katalog duchowieństwa, t. 4, s. 1376.

${ }^{60}$ Ibidem, t. 3, s. 912.

${ }^{61}$ ADK II PB-XI/5, s. 60.

${ }^{62}$ Hierarchia catholica medii et recentioris aevi, sive Summorum pontificum, S.R.E. cardinalium, ecclesiarum antistitum series, t. 6, red. R. Ritzler, P. Sefrin, Padua, s. 234, 453; P. Mazur, Poczet biskupów chełmskich obrządku łacińskiego, Chełm 2012, s. 9. 
został przyjęty 15 czerwca 1782 r., na sześć miesięcy. Posiadał też aprobatę do spowiadania z 7 maja 1782 r., podobnie jak aplikację na pół roku. Odbył również swoje rekolekcje w seminarium kieleckim. Natomiast w 1791 r. na wikariat w Brzezinach zatrudniony był - ks. Dominik Gaiewski. Duchowny, urodzony w 1754 r., pochodził z powiatu chęcińskiego, a więc z tego samego, w którym znajdowała się parafia. Święcenia kapłańskie otrzymał 1 czerwca 1784 r. z prawem prowizji na parafię Lisów. Z tej posługi zrezygnował jednak 1 marca 1789 r. Trzy miesiące później, otrzymał prowizję na parafię brzezińską. Według opinii proboszcza zachowywał się przyzwoicie ${ }^{63}$.

Ksiądz Dachnowski sporządził Opis Stanu Kościoła i Beneficjum w Brzezinach z polecenia biskupa krakowskiego Feliksa Pawła Turskiego (1790$1800)^{64}$. Opis ten był formularzem przedwizytacyjnym. Ostatni ordynariusz na Wawelu w dobie staropolskiej miał bowiem zamiary przeprowadzenia wizytacji całej diecezji krakowskiej. Dokument sporządzony przez ówczesnego proboszcza składa się z 18 paragrafów i zawiera szczegółowy opis parafii, zbliżony pod względem zakresu do materiału lustrowanego w czasie wizytacji kanonicznej. Został sporządzony w dwóch egzemplarzach, a jego zgodność z oryginałem potwierdził 24 maja 1791 r. Wojciech Czapieżyński, kanonik kielecki, dziekan bodzentyński i pleban parafii Dębno ${ }^{65}$. Proboszcz Dachnowski zmarł 11 kwietnia $1792 \mathrm{r}^{66}$, posiadając godność kanonika kieleckiego ${ }^{67}$. Opatrzony sakramentami został pochowany w krypcie kościelnej.

Ostatnim plebanem parafii Brzeziny w okresie staropolskim był ks. Sebastian Grzybowski ${ }^{68}$, profesor Świętej Teologii ${ }^{69}$. Był on długoletnim profesorem seminarium kieleckiego ${ }^{70}$. Został on wprowadzony na urząd proboszcza brzezińskiego 21 kwietnia $1792 \mathrm{r}^{71}$ Duchowny ten pełnił również przez krótki czas funkcję wiceregensa (styczeń 1796 - czerwiec 1796) a następnie regensa $^{72}$ seminarium duchownego w Kielcach w latach 1799-1800 ${ }^{73}$. Zmarł 9 stycznia $1800 \mathrm{r} ., \mathrm{w}$ wieku 42 lat $^{74}$.

${ }^{63}$ ADK II PB-XI/I, s. 12.

${ }^{64}$ Ibidem, s. 6; B. Kumor, Dzieje, t. 1, s. 533-534.

${ }_{65}$ ADK II PB-XI/5, s. 76, 82.

${ }^{66}$ ADK PBRZ 30/1792.

${ }^{67}$ ADK II PB-XI/5, s. 76.

${ }^{68}$ Ibidem; J. Szczepaniak, Spis, s. 30.

${ }^{69}$ ADK II PB-XI/5, s. 82.

${ }^{70}$ F. Puchalski, Seminarium kieleckie, s. 49.

71 Ibidem; J. Szczepaniak, Spis, s. 30.

${ }^{72}$ Regens - przełożony seminarium; T. Wytrwał, Regens, [w:] EK, t. 16, k. 1312.

73 T. Wróbel, Dzieje seminarium duchownego w Kielcach na przestrzeni 250 lat, [w:] Księga jubileuszowa 1727-1977, Kielce 1977, s. 80.

74 Ibidem. 
Podsumowując, parafia Brzeziny posiadała w okresie staropolskim proboszcza, a czasowo, również jednego wikarego. Zastępcy plebana byli zatrudniani na oba rodzaje umów - aplikacja i prowizja, jednak dominujący typem była ta druga. Skąpa baza źródłowa nie pozwala na dokładne omówienie zagadnienia duchowieństwa w XV i XVII w. Do początku osiemnastego stulecia w parafii pracowało co najmniej pięciu kapłanów. Lata 1701-1795 są natomiast już lepiej udokumentowane, dzięki czemu możliwe jest pełne zbadanie prawie całego zagadnienia. Pierwszym proboszczem w XVIII w. był ks. Wawrzyniec Cedrowicz. Tę funkcję pełnił łącznie 27 lat, a w czasie jego posługi zatrudnił łącznie co najmniej dwóch wikarych. Jeden z nich, Kazimierz Maliński został mianowany jego następcą. W ciągu całego stulecia, a być może i całego okresu staropolskiego w dziejach parafii to on najdłużej piastował swoje stanowisko - 32 lata. Nie zatrudniał on żadnego wikarego, z racji braku odpowiedniego uposażenia, ale w pewnym czasie miał pomoc w postaci franciszkanina. Po śmierci ks. Malińskiego rozpoczyna się okres w historii parafii, kiedy to proboszczami zostają duchowni ze Zgromadzenia Księży Życia wspólnego, opiekujący się Seminarium Duchownym w Kielcach, co wyróżnia parafię na tle innych wspólnot. Stan ten będzie trwał aż do połowy XIX w., jednak omówienie tego tematu wykracza poza zakres niniejszego artykułu. Kolejni proboszczowie - Andrzej Dachnowski i Sebastian Grzybowski byli profesorami teologii, pełnili też różne funkcje kierownicze w seminarium. Kapłani ci posiadali więc lepsze wykształcenie niż ich poprzednicy, co będzie się przekładało również na jakość duszpasterstwa parafialnego. Prawo patronatu kieleckiego seminarium do parafii Brzeziny powodowało również, iż beneficjum parafii było przeznaczone jako tytuł kanoniczny do święceń dla 2-3 alumnów z Kielc, z czego chętnie korzystał ks. Dachnowski, zatrudniając (bądź tylko dając tytuł) łącznie dla czterech wikarych. Biorąc pod uwagę powyższe, pełnienie funkcji proboszcza w parafii Brzeziny dawało możliwość uzyskania stałych dochodów, w sytuacji, gdy ówczesnych plebanów absorbowała głównie praca w kieleckim seminarium. Z kolei dla młodszych kapłanów, Brzeziny były jedną z wielu parafii, na której mogli się znaleźć na różnych etapach kariery duchownego. Badając jeszcze pochodzenie terytorialne duchowieństwa parafii Brzeziny, należy zwrócić uwagę, iż prawie wszyscy księża w okresie staropolskim - z wyjątkiem wikarego Dominika Gaiewskiego - pochodzili spoza najbliższej okolicy. W dwóch przypadkach natomiast księża posługujący na parafii byli przybyszami z okolic Kielc - Masłów - i Jędrzejowa - Korytnica. Większość kapłanów - jeżeli jest możliwe określenie ich pochodzenia - przybyła do Brzezin z innych stron ówczesnej diecezji krakowskiej. 
Na zakończenie warto zwrócić uwagę na to, iż zagadnienie duchowieństwa parafialnego w epoce potrydenckiej - również parafii Brzeziny - ściśle łączy się z dwoma innymi problemami badawczymi - uposażeniem parafii i duszpasterstwem. Dobrym przykładem tego powiązania jest kwestia inkorporacji beneficjum parafii Brzeziny do kieleckiego seminarium. Stąd kwestia duchowieństwa parafialnego może stanowić punkt wyjścia do badania całościowego dziejów parafii.

\section{BIBLIOGRAFIA}

\section{Źródła rękopiśmienne}

Archiwum Kurii Metropolitalnej w Krakowie (AKMKr)

AKMKr AV Cap 8, s. 1, 61-62.

AKMKr AV 17, s. 432-534.

AKMKr AV 27, s. 41-46, 269-277.

AKMKr AV 37, s. 89-94, 402-414.

Archiwum Diecezjalne w Kielcach (ADK)

ADK II PB-XI/5 rkps, s. 54r-61r.

ADK II PB-XI/1 rkps, s. 6r-13r.

ADK APBRZ rkps, 13/1769.

\section{Źródła drukowane}

Długosz J., Liber beneficiorum dioecesis Cracoviensis, t. 1. red. A. Przezdziecki, Kraków 1864, s. 457. Dokumenty soborów powszechnych, t. IV, oprac. A. Baron, H. Pietras, Kraków 2004.

\section{Opracowania}

Ataman J., Zarys dziejów diecezji przemyskiej obrzq̨dku łacińskiego, Przemyśl 1985.

Brudisz M., Księża Życia Wspólnego, [w:] Encyklopedia katolicka, t. 10, Lublin 2004, k. 118-123. Budka W., Białobrzeski Marcin, [w:] PSB, t. 2, Kraków 1936, s. 14-15.

Dymnicka-Wołoszyńska H., Antoni Kazimierz Ostrowski, [w:] PSB, t. 24, 1979, s. 540-546.

Glemma T., Wizytacje diecezji krakowskiej z lat 1510-1570, „Nasza Przeszłość” 1946, t. 1, s. 43-96.

Główka D., Przewodnik, inicjator, adwersarz? Uwagi o miejscu plebana w społeczności wiejskiej w XVII-XVIII wieku na przykładzie diecezji płockiej, [w:] Dwór, plebania, rodzina chłopska, Szkice z dziejów wsi polskiej XVII i XVIII wieku, red. M. Ślusarska, Warszawa 1998, s. 55-67. 
Górski E., Święcenia niższe i wyższe. Studium liturgiczne-historyczne, Sandomierz 1954.

Hierarchia catholica medii et recentioris aevi, sive Summorum pontificum, S.R.E. cardinalium, ecclesiarum antistitum series, vol. VI, red. R. Ritzler, P. Sefrin, Padwa 1958.

Jougan A., Słownik kościelny łacińsko-polski, Warszawa 1958.

Konopka M., Organiści w archidiakonacie sandomierskim $w$ XVIII wieku (na podstawie akt wizytacyjnych), „Studia Organolocia” 1998, t. 2, s. 57-70.

Kowalski W., Change in Continuity: Post-Tridentine Rural and Township Parish Life in the Cracow Diocese, „Sixteenth Century Journal” 2004, 35.3, s. 689-715.

Kowalski W., Opieka szpitalna i dobroczynność na terenie archidiakonatu sandomierskiego $w$ dobie przedrozbiorowej, [w:] Charitas. Miłosierdzie i opieka społeczna w ideologii, normach postępowania i praktyce społeczności wyznaniowych w Rzeczypospolitej XVI-XVIII wieku, red. U. Augustyniak, A. Karpiński, Warszawa 1999, s. 167-186.

Kowalski W., Parafia Trójcy Świętej w Jędrzejowie w epoce przedrozbiorowej, [w:] W. Kowalski, D. Olszewski, Parafia Trójcy Świętej w Jędrzejowie na tle dekanatu. Zarys dziejów, Kielce 2003, s. 7-226.

Kowalski W., Uposażenie parafii archidiakonatu sandomierskiego w XV-XVIII wieku, Kielce 1998.

Kracik J., Potrydencki system rekrutacji duchowieństwa $w$ diec. krakowskiej XVI-XVII wieku, „Analecta Cracoviensa” 1978, t. 10, s. 484-488.

Kumor B., Diecezja tarnowska. Dzieje ustroju i organizacji 1786-1985, Tarnów-Kraków 1985.

Kumor B., Dzieje diecezji krakowskiej do roku 1795, t. 1-4, Kraków 1998-2002.

Le Goff J., Sakiewka i życie. Gospodarka i religia w średniowieczu, Gdańsk 1995.

Liedtke A., Zarys dziejów diecezji chełmińskiej do 1994, Pelpin 1994.

Litak S., Parafie w Rzeczypospolitej w XVI-XVIII wieku. Struktura, funkcje społeczno-religijne i edukacyjne, Lublin 2004.

Litak S., Struktura i funkcje parafii w Polsce, [w:] Kościół w Polsce, t. 2, red. J. Kłoczowski, Kraków 1969.

Mazur P., Poczet biskupów chełmskich obrzq̨dku łacińskiego, Chełm 2012.

Nowicki T., Kościół, duchowieństwo i parafianie fordońscy według wizytacji kanonicznej z 25 października 1781 r., „Kronika Bydgoska” 1998, t. 19, s. 290-291.

Olczyk A., Sieć parafialna biskupstwa warmińskiego do roku 1525, Lublin 1961.

Puchalski F., Seminarium kieleckie. Rys historyczny i dokumenty, Kielce 1901.

Rzewuska-Kurzeja B., Rozwój sieci parafialnej w prepozyturze kieleckiej w średniowieczu, „Nasza Przeszłość” 1983, t. 59, s. 70-96.

Scharnagl A., Kirchebeamte, [w:] Lexikon für Theologie und Kirche, t. 5, Freiburg im Breisgau 1933, s. 997.

Skierska I., Obowiq̨zek mszalny w średniowiecznej Polsce, Warszawa 2003.

Szafran P., Rozwój średniowiecznej sieci parafialnej w Lubelskiem, Lublin 1998.

Szczepaniak J., Duchowieństwo diecezji krakowskiej w XVIII wieku. Studium prozopograficzne, Kraków 2010.

Szczepaniak J., Katalog duchowieństwa diecezji krakowskiej na podstawie krakowskich ksiąg święceń (1646-1789), t. 1-4, Kraków 2008-2009.

Szczepaniak J., Katalog parafii i duchowieństwa diec. krakowskiej 1748, Kraków 2006. 
Szczepaniak J., Spis prepozytów i plebanów diecezji krakowskiej, Kraków 2008.

Tazbir J., Staropolski antyklerykalizm, „Kwartalnik Historyczny” 2002, z. 3, s. 13-22.

Tazbir J., Znaczenie obyczajów kleru dla rozwoju i upadku polskiej reformacji, „Odrodzenie i Reformacja w Polsce" 1963, t. 8, s. 91-107.

Wiśniewski J., Dekanat miechowski, Radom 1917.

Wiśniewski J., Dekanat opatowski, Radom 1907.

Wiśniewski J., Dekanat radomski, Radom 1911.

Wiśniowski E., Parafie w średniowiecznej Polsce, Lublin 2004.

Wojciechowski G., Prezenta, [w:] Encyklopedia katolicka, t. 16, Lublin 2012, k. 394-395.

Wróbel T., Dzieje seminarium duchownego w Kielcach na przestrzeni 250 lat, [w:] Księga jubileuszowa 1727-1977, Kielce 1977, s. 51-175.

Wytrwał T., Regens, [w:] Encyklopedia katolicka, t. 16, Lublin 2012, k. 1312-1313.

\section{Tomasz Korban}

\section{LOWER CLERGY OF POSTTRIDENTAL EPOCH IN THE LIGHT OF BISHOPS' VISITATION PROTOCOLS. THE EXAMPLE OF PARISH OF ALL SAINTS IN BRZEZINY}

IN the article it had been presented lower clergy of posttridental time in example of Brzeziny parish. This community in Old-Polish period belonged to Cracow diocese. As a main source to research those issue were used acts of canonical visitations. The structure of article is chronological to subsequented periods of priest's service, who worked in parish from $16^{\text {th }}$ to $18^{\text {th }}$ century. In description of priests included information about their roots, education, priest's career and also moral attitudes. The picture of Brzeziny parish clergy had been compared with the state of researches about clergy in posttridental times, which assumption was amplification of priest's role in church community.

Keywords: Council of Trent, Counter-reformation, Krakow diocese, lower clergy, Brzeziny. 